\title{
Detection and quantification of Trypanosoma vivax by real-time PCR in experimentally infected cattle
}

Otavio Luiz Fidelis Junior ${ }^{[a]}$, Paulo Henrique Sampaio ${ }^{[a]}$, Luiz Ricardo Gonçalves ${ }^{[a]}$, Priscila Preve Pereira ${ }^{[a]}$, Kayo José Garcia de Almeida Castilho Neto ${ }^{[a]}$, Marcos Rogério André[a], Rosangela Zacarias Machado ${ }^{[a]}$, Fabiano Antonio Cadioli ${ }^{[a, b]^{*}}$

\footnotetext{
[a] Faculdade de Ciências Agrárias e Veterinárias, Universidade Estadual Paulista (UNESP), Jaboticabal, SP, Brazil

${ }^{[b]}$ Faculdade de Medicina Veterinária, Universidade Estadual Paulista (UNESP), Araçatuba, SP, Brazil
}

*Corresponding author

e-mail: fabianocadioli@fmva.unesp.br

\begin{abstract}
Trypanosoma vivax spreads in herds worldwide mainly by the introduction of animals in chronic phase of the infection, where parasitaemia is low and intermittent, which makes diagnosis challenging. Direct T. vivax visualization still the more widely used method for the disease diagnosis, but is inaccurate in low parasitaemia. The aim of the present study was compare Brener technique (BT) and real time PCR (qPCR) for T. vivax detection and parasitemia quantification during the course of the disease. Three Girolando cows were experimentally infected with $2.0 \times 10^{7}$ trypomastigotes of T. vivax and whole blood in EDTA were collected of each cattle, on days $-7,0,1$ and then every seven days up to 119 days after infection (DAI). BT was performed using $5 \mu \mathrm{L}$ of whole blood in a microscope slide under a 22 × $22 \mathrm{~mm}$ coverslip and, trypomastigotes were counted in 50 microscopic fields at 40X objective. qPCR was conducted using the TaqMan system. Reactions were performed using $5 \mu \mathrm{L}$ of genomic DNA (except for negative control), $200 \mathrm{nM}$ of each primer, $160 \mathrm{nM}$ of T. vivax probe, $120 \mathrm{nM}$ of TLR-8 probe, buffer 2X (6 nM MgCl2, $0.8 \mathrm{mM}$ dNTPs, 1 U Taq DNA polymerase) in a final volume of $25 \mu \mathrm{L}$. Amplifications were conducted in duplicate in a CFX96 thermal cycler (initial denaturation at $95^{\circ} \mathrm{C} / 10 \mathrm{~min}$, followed by 45 cycles of $95^{\circ} \mathrm{C} / 30 \mathrm{~s}, 61^{\circ} \mathrm{C} / 1 \mathrm{~min}$, and ended with $72^{\circ} \mathrm{C} / 1 \mathrm{~min}$ ). The analytical sensibility was tested with gBlock $^{\circledR}$ Gene fragments targeting sequences for T. vivax ITS-1 region and serial dilutions were made to construct patterns with different concentrations of gBlock ${ }^{\circledR}$ targets $\left(2.0 \times 10^{7}\right.$ to $2.0 \times 10^{0}$ copies $\left./ \mu \mathrm{L}\right)$. The copies number was determined according to the formula $(\mathrm{Xg} / \mu \mathrm{L} \mathrm{DNA} /$ [gBlock $^{\circledR}$ size (bp) x 660]) x $6.022 \times 10^{23}$ x copies of gBlock $\left.^{\circledR} / \mu \mathrm{L}\right)$. BT detected $31.48 \%(17 / 54)$ of known positive samples, of which $76.47 \%$ (13/17) were detected within 7 to 35 DAI for all three cows and the parasitaemia range was 8,100 up to $16,248,600$ parasites/mL. All samples were positive for the endogenous gene (TLR-8), indicating that extractions were efficient, and giving reliability to the results obtained by qPCR, which detected 61.11\% (33/54) of known positive samples and parasitaemia range was 19.2 up to
\end{abstract}


270,000,000 parasites/mL. Positive correlation between the two techniques was found $(\mathrm{P}<0.0001$ and Spearman $r=0.8757$ ). This is the first time that qPCR was used for detection and quantification of American T. vivax isolates. These results suggest that qPCR can be used as an accurate tool for T. vivax detection and quantification, even between acute and chronic phases, where low and intermittent parasitemia lead to false negative results in direct parasitological tests. 